Cheng, J. H., \& Shen, Z. J. (2019). Planning Support Tool for Checking Building Form Legality with Augmented Reality. Landscape Architecture Frontiers, 7121, 132-143. https:// doi.org/10.15302/J-LAF-20190213

\section{基于增强现实的规划支持工具: 以建筑形态合规性检验为例 PLANNING SUPPORT TOOL FOR CHECKING BUILDING FORM LEGALITY WITH AUGMENTED REALITY}

1 引言

规划支持系统 (PSS) 是一种应用系统性、动态化和交互性计算机 技术来辅助城市规划与设计的工具 ${ }^{[1][2]}$, 目前已被应用于城市开发预 测 ${ }^{[3]-[5]}$ 、空间规划 ${ }^{[6][7]}$ 、基础设施选址 ${ }^{[8][9]}$ 、城市景观设计 ${ }^{[10[11]}$ 等领域。 然而, 当前大多数PSS或仅支持二维信息的可视化 ${ }^{[3]-6 \mid[\mid 8[10]}$, 或仅能在 三维虚拟环境下运行 ${ }^{[2] 17190[11]}$, 无法使用户感知现实世界并与之互动。

而正在兴起的增强现实 $(\mathrm{AR})$ 技术则可将虚拟的数字模型与真实 物体相叠加, 以提供沉浸式用户体验, 并使实时环境设计成为可能 ${ }^{[12[13]}$ 。 基于AR技术的应用程序对硬件要求不高、易于操作，适用于智能手机、 平板电脑等多种移动设备。

20 世纪 90 年代, 航空领域首先引人 $A R$ 技术用于飞行员培训 ${ }^{[14]}$ 。当 前, 这一技术已被推广至医学科学 ${ }^{[15[16]}$ 、教育 ${ }^{[17][18]}$ 、行为研究 ${ }^{[19]}$ 、建筑

\section{程娇华}

福建农林大学东方学院助教

沈振江

日本国立金泽大学环境设计学院教授; 日本工程院外籍院士

摘要

本文以日本《建筑标准法》规定下建筑形态 管理的合规性检验为例，开发了一种基于增强现 实技术的规划支持工具（AR-PST），其可将虚 拟现实建筑模型、建筑规范与真实场地相结合, 以检验设计方案是否符合相关建筑规范或设计指 南。用户可以在移动设备 (如智能手机、平板 电脑等) 上使用此工具与建筑模型进行互动, 更 充分地了解设计方案及其对真实建筑场地环境的 可能影响，以对其进行更精确的评估。在此基础 上, 研究通过问卷调查和访谈的方式开展了ARPST的用户体验测试。结果表明, 此工具具有创 造性的功能设计和良好的交互性，可以提高设计 师与用户之间的沟通效率并为城市规划与设计工 作提供帮助。

\section{关键词}

增强现实; 城市设计; 建筑规范; 三维模型; 规 划支持工具
CHENG Jiaohua

Teaching Assistant of the Dongfang College, Fujian University of Agriculture and Forestry

SHEN Zhenjiang*

Professor of School of Environmental Design, Kanazawa University; Foreign Associate of the Engineering Academy of Japan

*Corresponding Author

Address: School of Environmental Design Kanazawa Universitym Kakuma-chi, Kanazawa, Ishikawa, 920-1 192 , Kapan E-mail: fcl.shen@gmail.som

\section{ABSTRACT}

In this research, we used Augmented Reality technology to develop a planning support tool (ARPST) which combines virtual building models and building regulations with a real site to effectively check whether design alternatives obey the building regulations or design guidelines, and realizes detection of violations of the building form control regulations under the Building Standards Law of Japan. Through the AR-PST, the users can interact with the building models using mobile devices (such as smart phones and tablets) to further understand design proposals as well as their influence on the environment around the real construction sites to achieve a more reasonable evaluation of them. User experience investigation for this tool was then carried out via questionnaire and interview. The results show that the ARPST has creative functional design and good interactivity which can improve the communication efficiency between designers and users and assist urban planning and design.

\section{KEY WORDS}

Augmented Reality; Urban Design; Building Regulations; 3D Model; Planning Support Tool
编辑 王颖 王胤瑜 翻译 李慧彦

EDITED BY WANG Ying WANG Yinyu TRANSLATED BY LI Huiyan 
1. 日本6类住宅用地的部分 建筑形态规范

Parts of the building form control regulation for 6 residential zones in Japa
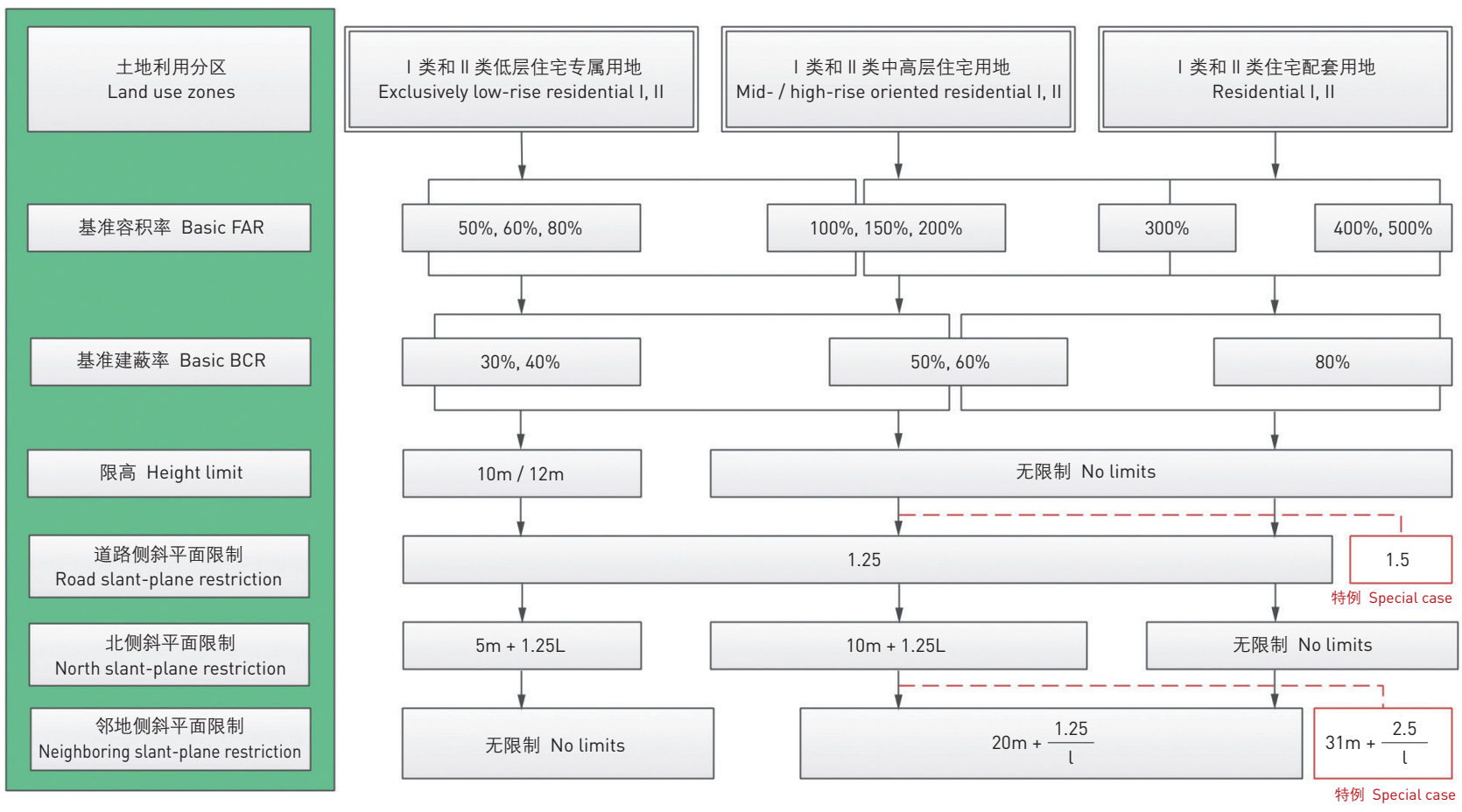

｜ 类低层住宅专属用地中许可的建筑类型可包含小型商业或办公空间, 以及初、高中学校的住宅类建筑; || 类低层住宅专属用地中许可的建筑类型除初、高中学校外, 还包含首层 面积不超过 $150 \mathrm{~m}^{2}$ 的商业空间。

2. | 类中高层住宅用地主要用于建造中高层住宅类建筑。除了医院和大学建筑外, 还包含首层面积不超过 $500 \mathrm{~m}^{2}$ 的商业空间; || 类中高层住宅用地中许可的建筑类型除医院和大学建 筑外，还包含首层面积不超过 $1500 \mathrm{~m}^{2}$ 的、为当地社区提供便利服务的商业空间。

3. I 类住宅配套用地用于建设居住环境的配套设施，许可的建筑类型包括首层面积不超过 $3000 \mathrm{~m}^{2}$ 的商业空间、办公空间和酒店; II 类住宅配套用地中许可的建筑类型除商业空间、 办公空间和酒店外，还包含娱乐场所。

4. 图中数据来源于日本《建筑标准法》, 更多有关该法规的内容可访问日本“电子政务综合窗口”（e-Gov Japan）获取。

Notes:

1. The permitted buildings of the category I exclusively low-rise residential zone include residential buildings which are also used as small shops or offices and elementary / junior high school buildings; In addition to elementary / junior high school buildings, certain types of the permitted buildings of the category II exclusively low-rise residential zone include shop buildings with a floor area of up to $150 \mathrm{~m}^{2}$ are permitted.

2. Category I mid / high-rise oriented residential zone is designated for medium to high residential buildings. In addition to hospital and university buildings, certain types of shop buildings with a floor area of up to $500 \mathrm{~m}^{2}$ are permitted; In addition to hospital and university buildings, the permitted buildings of category II mid / high-rise oriented residential zone include certain shops and office buildings with a floor area of up to $1,500 \mathrm{~m}^{2}$ to provide conveniences for the local community.

Cate to $3,000 \mathrm{~m}^{2}$; In addition to shops, offices, and hotel buildings, the permitted buildings of category II residential zone include buildings with karaoke box.

to $3,000 \mathrm{~m}^{2}$; In addition to shops, offices, and hotel buildings, the permitted buildings of category II residential zone include buildings wh
4. Data source: Building Standards Law of Japan. Please visit the official website of e-Gov Japan for more information on this regulation.

设计、工程和建设 ${ }^{201}$ 等领域; 据由权威游戏市场调查公司Digi-Capital平 台发布的《2015年AR/VR发展报告》估计，到2020年，AR技术的市场 份额将达到近1 200亿美元，比2014年激增近5万倍 ${ }^{[21]}$ 。在城市规划设 计领域, AR也作为一种新技术推动了文化遗产保护 ${ }^{[22] 23]}$ 与智慧城市建 设 ${ }^{[24 \mid 25]}$ 。

近年来，城市规划与设计的决策越发注重吸纳所有利益相关方的 意见（包括普通居民和城市管理者） ${ }^{[26]}$; 另一方面，在高密度城市环境 中进行建设需遵循的规划设计条例十分复杂, 非专业人士往往对其并 不了解 ${ }^{[2] 110]}$, 在上述决策中的参与度非常有限。因此, 公众参与者迫 切需要了解城市规划设计条例的渠道。当前的虚拟现实 (VR) 等技术
虽然已能实现城市规划与设计方案的3D可视化与虚拟漫游等功能, 但无法在虚拟建筑模型与真实建筑之间建立直观联系 ${ }^{[27]}$ 。因此，我 们研发了一种基于AR技术的规划支持工具（AR-PST），试图让使 用者能一边漫步于现实城市环境中，一边将虚拟3D建筑物投射到周 围的街道和地块上进行感知，以帮助提高城市规划与设计的公众参 与度。

这一面向移动设备的工具可基于规划设计方案生成虚拟建筑模 型，并结合相关条例与规范对其进行分析，得出可利用建设空间及其 与建筑形态控制要求的关系, 从而判断设计方案是否符合建筑规范或 设计指南。通过使用该工具，居民可在实际建设场地中与虚拟建筑模 


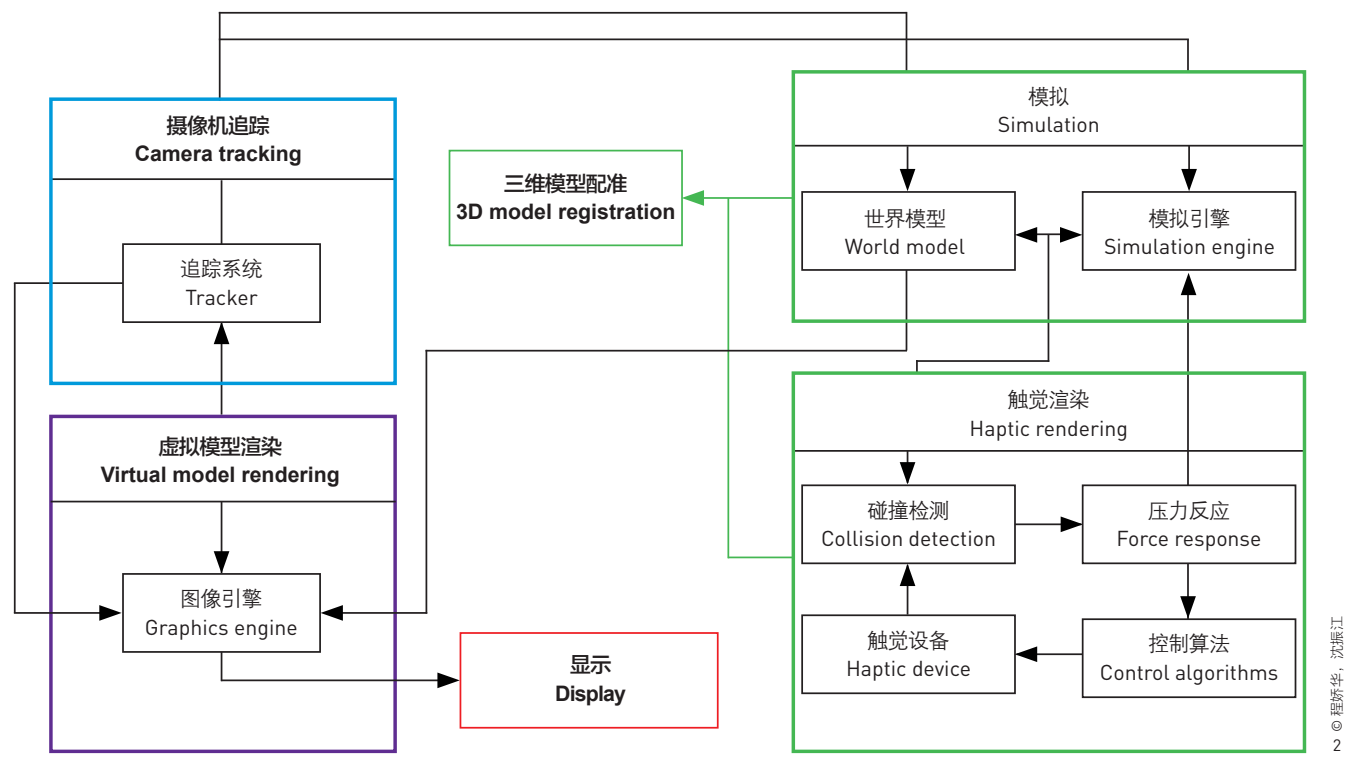

(1) 日本城市规划体系下的 街区规划规范比较完 善, 对建筑形态的限制 善, 对建筑形态的限制
起到了积极作用, 可以 为我国的城市规划提供 参考。

2. AR技术的系统框架

2. System framework of AR technology

型进行互动，以更充分地了解施行的设计方案和相关规划条例; 城市管 理者则可以发现规划设计方案的违规之处，以提高城市建设的效率。

\section{2 研究设计}

在本研究中, 上述AR-PST的开发工作主要基于安装了Vuforia SDK 插件的Unity 3D平台; 研究团队随后邀请了若干非城市规划与设计相关 专业的用户对此工具进行测评, 通过手动触摸等人机交互操作全面检 视虚拟建筑模型, 以结合相关建筑规范更好地理解和评估设计方案及 其对实际场地环境的可能影响; 最后对上述用户进行体验调查, 以检 验AR-PST能否有效提高设计师与用户之间的沟通效率, 以及是否为城 市规划与设计提供了帮助。

\section{1 街区规划规范}

本研究将日本城市规划体系下的建筑管理规范作为讨论对象 ${ }^{\circledR}$ 。 该规划体系首先将土地分为可开发区域和禁止开发区域; 在城市建 设中, 根据其具体用途, 可开发区域的土地被进一步划分为 12 类土地 利用分区; 各个城市可根据实际需要, 在土地利用分区层级上制定更 为详细的街区规划（District Plan）。本研究选取其中6类住宅用地利 用分区- I 类和 II 类低层住宅专属用地、I 类和 II 类中高层住宅用 地，以及 I 类和 II 类住宅配套用地（图1），探讨其街区规划层级上的 建筑规范。

街区规划规范的内容涵盖三个方面: 1) 公共设施选址, 如小型公
园、地方公路、人行道, 以及开放空间等; 2 ) 建筑控制规范, 包括土 地用途、建蔽率 (BCR) 、容积率 (FAR)、绿地率、建筑用地规模和 建筑退线控制; 以及 3 ) 绿地保护。其中, 建筑控制规范中的退线控制 又可具体分为道路侧斜平面限制、地块北侧斜平面限制、邻地侧斜平 面限制 ${ }^{[28]}$, 以及最易被忽略的 “角点 (切角) 建筑限制” , 前三者主要 用于保障人行道具有足够宽度, 切角的设置则使行人和机动车司机在 十字路口处的视野不受建筑遮挡, 以保障出行安全; 加之在土地和房 产交易中买家也往往更青睐位于道路交叉口的地段, 因此了解建筑的 切角控制规范尤为重要。本研究将上述建筑退线的合规性作为AR-PST 最主要的检测对象。

\subsection{AR技术}

如图2所示, AR系统通常由摄像机追踪、虚拟模型渲染、三维配准 和显示 4 个部分组成。其中, 摄像机追踪和虚拟模型渲染模块用于虚拟 世界与现实世界信息的叠加。三维配准是AR系统的核心, 主要分为仿 真和触觉渲染两部分, 用于辅助建筑规划, 但其在本研究中的应用仅 限于对建筑形态控制进行合规性检验。

\section{AR-PST的实现}

\section{1 系统架构}

本研究所研发的AR-PST主要由用户界面模块和数据处理模块组成 (图3)。 
(2) 图4即为 $A R$ 标记的一个 示例。AR标记可根据物 体的特征来坽测和识 部要 别其光照、局部重叠 和方向, 具备良好的 性能 ${ }^{[30]}$ 。

3. 本研究所开发的AR-PST 的系统架构

The system architecture of AR-PST developed in this research
用户界面模块是使用者与此工具互动的桥梁，主要包含 4 个与建筑 形态相关的操作功能：实时编辑、设计方案对比、可用空间计算及建 筑合规性检验。通过实时编辑功能, 用户可输人地块的大小和形状信 息, 并将设计方案模型叠加在地块上, 进行移动、缩放和旋转。设计 方案对比功能可切换模型的屋顶样式及建筑类型、改变模型的外观及 内部空间布局, 供用户感知、比较和评估不同方案中建筑物周边现实 环境的影响, 并选出更合理的方案。可用空间计算功能可显示不同方 案模型的实际容积率与建蔽率。在建筑合规性检验模块中, 用户首先 需选择方案地块的土地开发用途, 并设置好相关的建筑形态控制标准 参数, 如高度限制、道路斜平面限制、北侧斜平面限制和邻地斜平面 限制等; 而后，系统可通过Unity 3D平台的碰撞检测技术检验建筑模型 是否符合相应的建筑规范。

数据处理模块分为成像层、整合层和渲染显示层三个层级。成像 层由用于成像和标记 ${ }^{2}$ 采集与追踪的各种组件构成。整合层由 $\mathrm{C}$ \#脚本 库和核心的Unity物理引擎及图形引擎组成, 衔接着成像层和渲染显示 层; 该层级可向图像处理器 (GPU) 发出绘制指令以创建虚拟建筑模 型, 并在虚拟三维环境中对模型进行定位。渲染显示层采用虚拟模型 渲染技术，对从整合层获取的数据（包括真实场地图像、AR标记的特 征点、虚拟建筑模型等) 进行处理, 并将结果输出到移动设备终端。

\section{2 三维建模和摄像机设置}

完成AR-PST的开发之后，研究先使用3D Studio Max软件创建 了若干形态不同的三维建筑模型，并以Unity资源包为匹配坐标，在
ImageTarget 层级中进行三维模型配准（图5）。

操作的第二步是设置AR摄像机。AR摄像机可以采集现实场地的图 像并生成渲染背景，以便用户将虚拟建筑模型投射到上面观看，从而 实现虚拟设计方案与现实世界的结合。在AR-PST系统中可以切换摄像 机视椎体 (FRUSTUM) 的投影类型, 调整平面和视口矩形的大小, 亦 可对 $\mathrm{AR}$ 摄像机的方向、设备模式、镜像视频背景及全球中心模式等参 数进行设置。摄像目标可通过脚本代码来设置。摄像机检测到目标物 体后，目标对象将被导人到系统项目中，并将其图像信息存储为XML 文件以便调用。

\section{3 基于碰撞检测的建筑退线合规性检验}

碰撞检测模块是AR-PST实现建筑合规性检测功能的关键。图6与 图7以建筑切角合规性检测为例，展示了该模块的设计与工作原理。 AR-PST使用碰撞触发器进行碰撞检测, 虚拟建筑模型即为碰撞体。当 检测过程中存在冲突 (即碰撞发生) 时, 碰撞触发器将发送一条触发 消息作为提示。研究人员可通过对比两个碰撞体的结构与其预期值来 检验建筑模型是否符合建筑的切角限制规范。

\section{4 用户体验调研}

\section{1 调研方法概述}

用户体验调研的结果能够客观反映AR-PST是否易于使用。调研的 主要内容包括AR-PST的功能、交互性和流畅性的体验, 体验数据可通

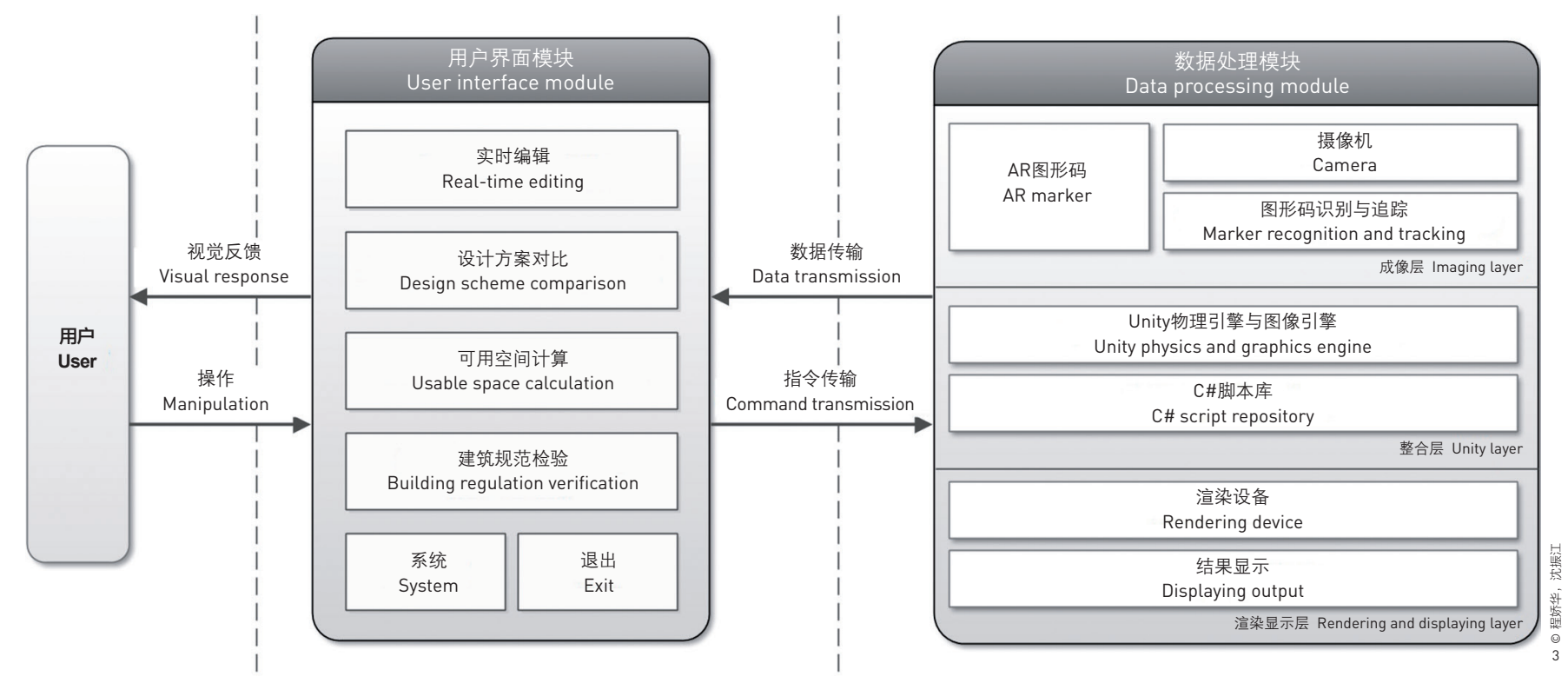



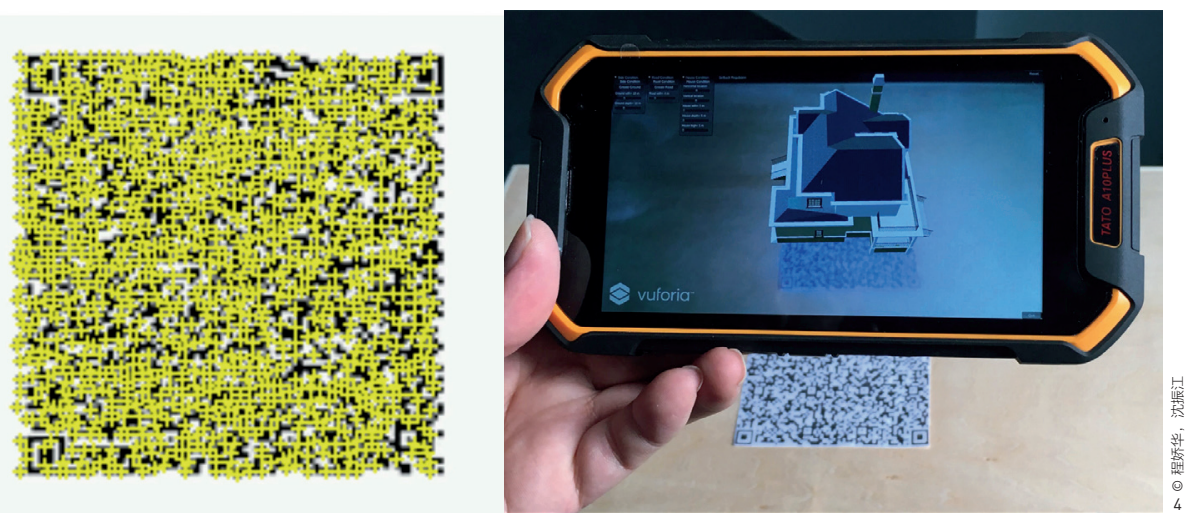

4. $\quad$ AR标识示例

4. An example of $A R$

marker

过参与者基本信息了解、操作体验及与参与者沟通三种途径获取 ${ }^{[31]}$ 。 2017年2月, 福州大学一日本国立金泽大学国际联合实验室对福州大学 20位非城市规划设计专业背景的学生进行了用户体验调研。

首先, 参与者使用平板电脑进人AR-PST的初始化页面（图8）, 该页面显示了AR-PST的名称，并说明了其用途是通过碰撞检测技术对 建筑形态的合规性进行检验。随后，参与者进人主菜单界面，以手动 触摸的方式测试各功能模块的效果及此工具整体的人机互动灵敏度。 整个调研均在福州大学校内的实际场地中进行 (图9)。最后, 参与者 需根据试用体验完成问卷调查, 问卷包含参与者基本信息、操作评价 和反馈调查三部分，其中后两部分采用修正里克特量表形式。

\section{2 调研结果分析}

内部一致性信度可反映问卷调查结果的一致性程度以及量表和问 卷调查的信度, 通常用克隆巴赫系数来表征, 该数值通过计算项目之 间的相关性得出, 取值范围为 $0 \sim 1$, 越接近 1 说明各调查项目之间的相 关程度越高, 量表或调查问卷的信度也越高。表 1 展示了本次用户体验 调研中操作评价量表和反馈调查量表的信度检验结果, 从中可知两部 分量表的克隆巴赫系数均在 0.70 以上, 即调研结果具有良好的可信度。

参与者的基本信息结果清晰地呈现了其对于AR-PST的倾向性。从 表2可见, $85 \%$ 的参与者对城市规划设计有着较深的理解。但参与者对 建筑规范的理解程度则远远低于对城市设计的理解。因此, AR-PST在 普及建筑规范方面有着较大的发展空间。同时, $75 \%$ 的参与者认为ARPST非常有趣且很有意义; 另有 $75 \%$ 的参与者支持将AR技术应用于城市 规划设计中, 其余参与者持反对意见的一个重要原因是认为 $\mathrm{AR}$ 技术的 发展还不够成熟, 虚拟建筑模型与实际项目地块的叠加契合度还有待 提高。

针对AR-PST进行的操作评价和反馈调查结果可参见表 3 。90\%的
参与者认为AR-PST可以提高设计师与用户之间的沟通效率，另有 $90 \%$ 的参与者认为各功能模块之间衔接顺畅; $85 \%$ 的参与者能够成功识别各 个功能模块; $80 \%$ 的参与者对人机交互界面的灵敏度非常满意。此外, $75 \%$ 的参与者认为AR-PST可以辅助城市规划与设计; $65 \%$ 的参与者表 示喜欢这款工具。与仅支持虚拟环境的传统PSS相比, AR-PST的主要 优势在于趣味性、交互性和灵活性: 趣味性表现在AR-PST能够以三维 空间模型的形式呈现建筑规范条例, 以帮助用户加深对规范文本的理 解; 交互性是指其能以手动触摸的方式实现灵敏的人机交互效果, 且 可以动态呈现设计方案; 灵活性在于其可轻松实现视角转换以及建筑 模型的实时编辑。

\section{5 结论}

本研究所研发的AR-PST可令用户在真实的建造场地中更好地理解 与评估相关规范指引下的建筑设计方案, 从而帮助提高设计师和用户 之间的沟通效率。用户体验测试结果表明, AR-PST具有创新的功能设 计和良好的交互性, 可以对建筑形态的合规性进行有效检验。本研究 的下一步工作是将AR-PST应用到更多的实际案例中, 以基于各项规划 规范更合理地分析建筑可用空间, 促进其在城市规划与设计中的更好 运用。LAF

\section{项目信息}

技术指导: 沈振江

研发团队（主要成员）：程娇华、张远翼、川上光彦

研发时间: 2016年

用户体验调研团队: 福州大学一日本国立金泽大学国际联合实验室学生 


\section{Introduction}

Planning support system (PSS) is a tool integrating systematic, dynamic, and interactive computer-based techniques ${ }^{[1]}$ to assist urban planning and design projects ${ }^{[2]}$, such as development prediction $^{[3] \uparrow[5]}$, spatial planning ${ }^{[6][]}$, urban infrastructure location $^{[8][9]}$, and urban landscape design ${ }^{[10][11]}$. However, most of the current PSSs either support 2D visualization ${ }^{[3] \sim 6[[8][10]}$ or run on $3 \mathrm{D}$ virtual environment ${ }^{[2][7][9][11]}$, through which the users can hardly perceive or interact with the real world.

An emerging immersive technology, Augmented Reality (AR), can overlap virtual digital components onto physical objects, realizing a real-time immersive environment design ${ }^{[12][13]}$. Combined with available hardware (such as smart phones and tablets), AR-based mobile applications can be easily operated by ordinary users.

Since its first introduction into pilot training ${ }^{[14]}$, the application of AR has expanded to medical sciences ${ }^{[15][16]}$, education ${ }^{[17][18]}$, human behavior research ${ }^{[19]}$, architecture, engineering, and construction ${ }^{[20]}$. According to the "AR / VR Q2 Report 2015" from Digi-Capital, an authorized investigation company of the game industry, the AR market is going to reach USD 120 billion by 2020 , nearly 50,000 times of that in $2014^{[21]}$. In urban planning and design, AR is also used as a new tool for cultural heritage conservation ${ }^{[22][23]}$ and smart city construction ${ }^{[24][25]}$.
In recent years, the decision-making in urban planning and design has increasingly emphasized the engagement of all stakeholders, especially the public users and urban managers ${ }^{[26]}$. On the other hand, construction in high-density urban environment is required to obey a series of complicated planning and design regulations that are difficult for nonprofessionals to understand and engage with ${ }^{[2][10]}$, which would impede the multi-party participation. Therefore, the public need a knowledge source to these regulations. Current technologies such as virtual reality (VR) have allowed for a $3 \mathrm{D}$ visualization of the schemes of urban planning and design, but they still fail connecting with the real world ${ }^{[27]}$. As a response, we turned to AR and developed a tool (AR-PST) with an expectation where the users can move around the real streets and neighborhoods while perceiving the virtual 3D buildings projected on them.

By generating and analyzing virtual building models with the related building form control regulations, the AR-PST for mobile devices can effectively work out the usable space for buildings in the real site, and figure out whether the proposal has made any violation. Through this interaction, residents can better understand the design proposals and regulations in real construction sites, and urban managers can discover the potential illegality in urban planning and design in time to improve the efficiency of urban construction.

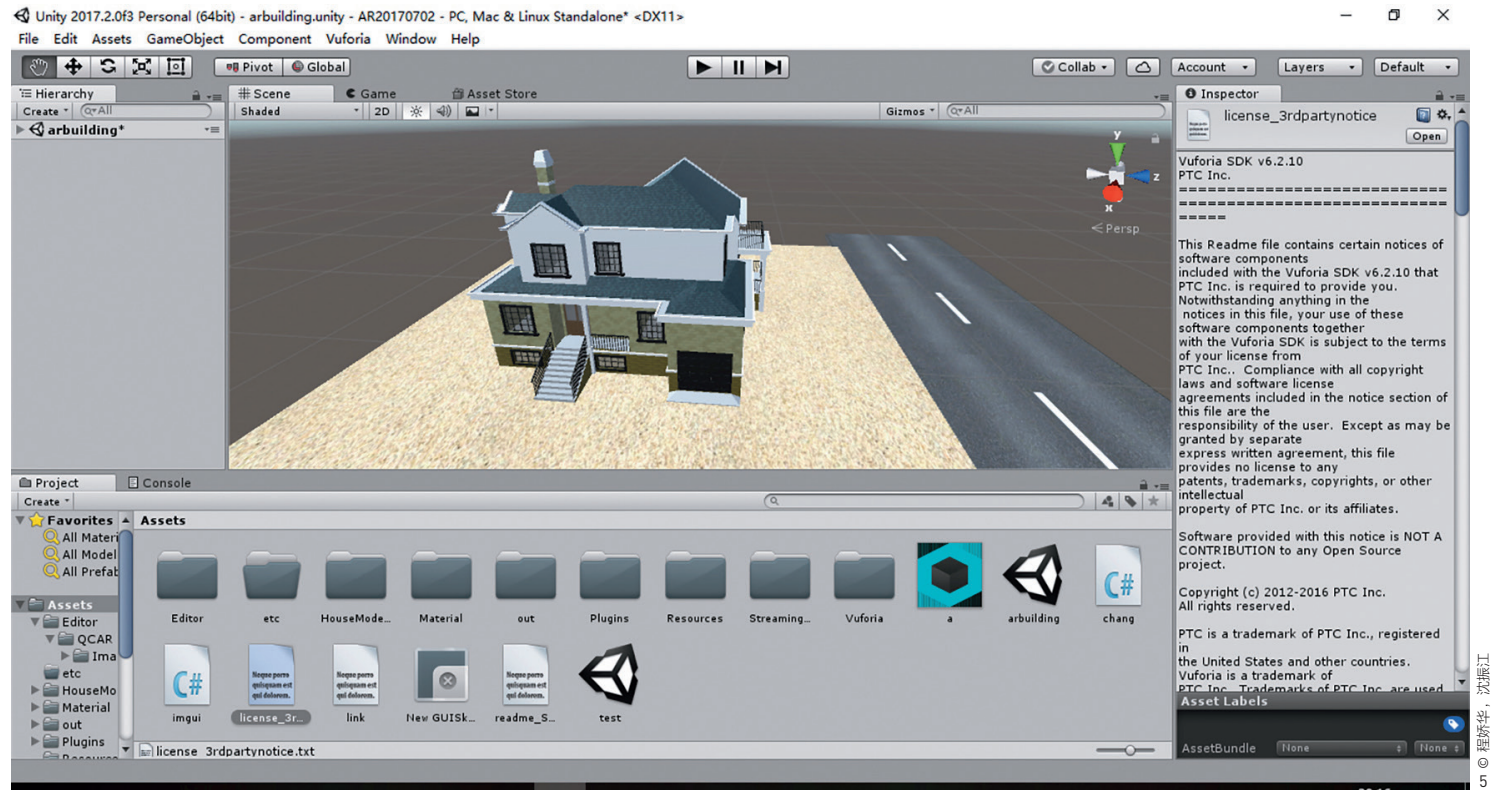

5. 供AR-PST检测的三维虚 拟建筑模型

5. A 3D virtual building model for AR-PST detection 

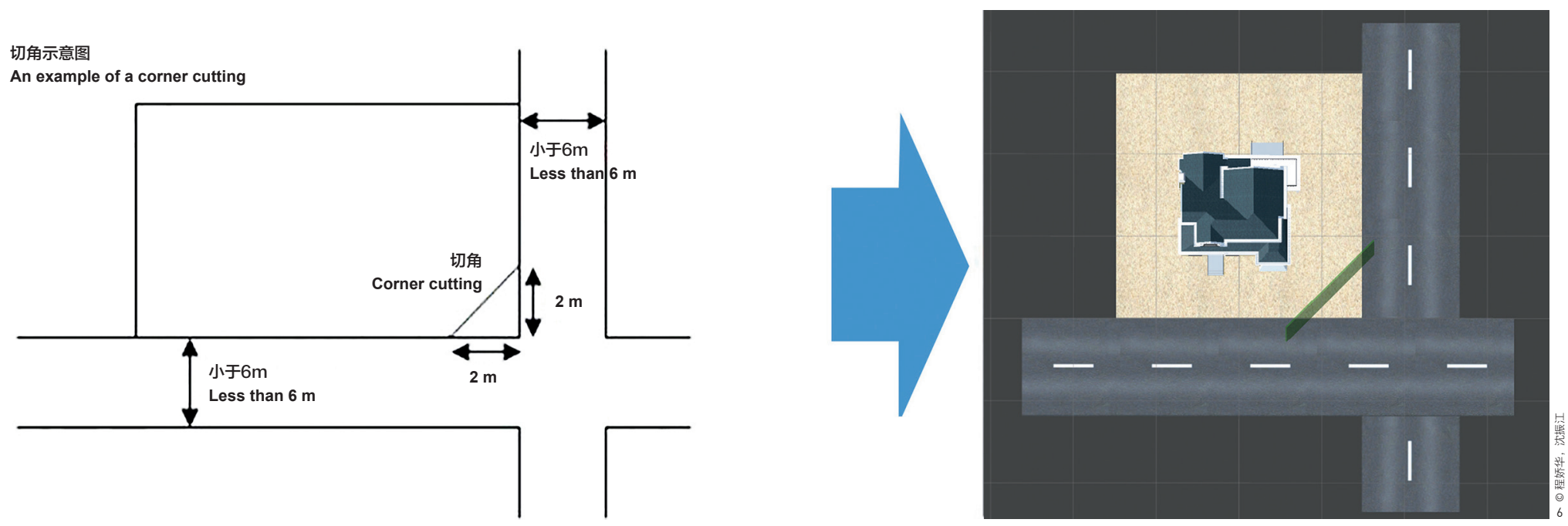

6. 道路转角处的建筑后退 红线

7. 碰撞检测中触发器 ( 中坚平面) 的状太变 中泣平面) 的状态变 化: 当它与另一个触发 器发生碰撞时就会发出 触发消息, 并改变颜色 作为提示。

6. Building setback line in a road corner

The state changes of a trigger lthe vertical plane) in collision detection: the triggers will send a trigger message and its color will also change as an alert when a collision occurs.
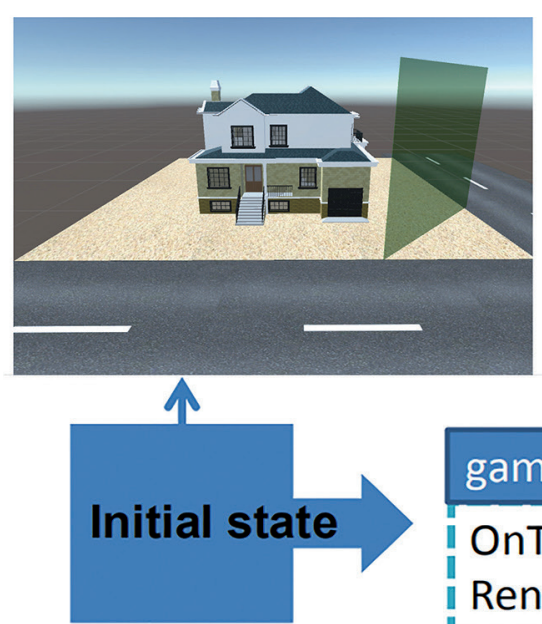

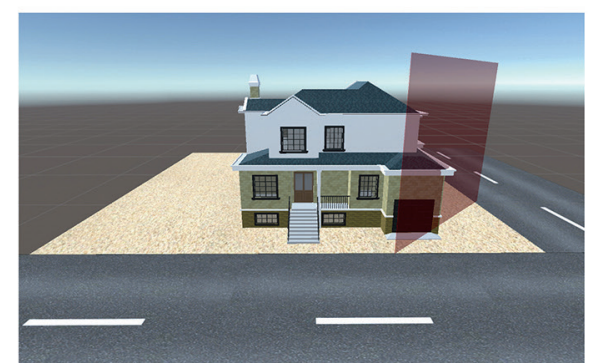

$\uparrow$

$$
\text { gameObject }
$$

OnTriggerEnter(Collider house) II Rend.sharematerial(1)

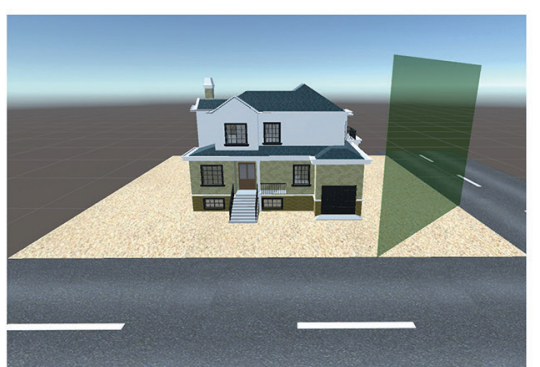

$\uparrow$

\section{gameObject}

OnTriggerEnter(Collider house) Rend.sharematerial $(0)$

\section{Research Design}

In this research, at first, an AR-PST was developed through the Unity 3D platform integrated with Vuforia SDK. Secondly, ordinary users were invited to test the interface and performance of the AR-PST: through examining the building models via human-computer interactions like manual touch, users can visualize the design proposals under the regulation framework, and evaluate the implementation impact on the site. Thirdly, a user experience investigation was conducted to assess the AR-PST's efficiency in designer-user communication and its performance in assisting urban planning and design.
2.1 Regulations under the District Plan

This research discusses the City Planning System in Japan ${ }^{(1)}$. In this system, land is first divided into Promotion Area (development promoted) and Control Area (development prohibited); for urbanization promotion area, the land is further classified based on specific purposes into 12 land use zones under which a detailed district plan can be schemed. We chose the 6 residential zones - exclusively low-rise residential zone I and II, mid / high-rise oriented residential zone I and II, and residential zone I and II (Fig. 1) - and focused on the regulations under the district plan of them.

Regulations under the district plan include three aspects: 1 ) 

the City Planning System in Japan is relatively perfect, they play a positive role in building form control regulation, which can provide references for urban planning in locations of public facilities, such as small parks, local roads, footpaths, and open spaces; 2) building form control, including land use, building coverage ratio (BCR), floor-area ratio (FAR), green space ratio, scale of building lot, and building setback line; and 3) green area preservation. In building form control, the building setback line is especially important for ensuring enough space for a wide pedestrian path. It is composed of slant plane restrictions of the road, north site, and adjacent site ${ }^{[28]}$, and the easiest to overlook, the restriction of the "horn site (commonly known as corner cutting)". It secures the safe view for pedestrians and vehicles at the intersections of roads. Moreover, considering the plots and houses at corner usually appeal more to purchasers, it is essential to understand the building control regulations on it. This research also takes the corner cutting restriction as a core detection item.

\subsection{AR Technology}

An AR system usually consists of four parts: camera tracking, virtual model rendering, 3D registration, and display (Fig. 2). Camera tracking and virtual model rendering are tools to combine the information of virtual and physical world. As the core of the AR system, 3D registration is composed of simulation and haptic rendering, which are conceived as a planning support but in this research only for the violation check against the building form regulations.

\section{Implementation of AR-PST}

\subsection{System Architecture}

The AR-PST developed in this research mainly consists of two modules: user interface module and data processing module (Fig. 3).

The user interface module, conceived to facilitate the interaction between the user and the tool, performs four functions related to the building form: real-time editing, design scheme comparison, usable space calculation, and building regulations verification. According to actual needs, the real-time editing function can input the size and shape parameters of a site, where the design proposal model can be overlaid, moved, zoomed, and rotated. Through the design scheme comparison, the user can switch the roof and type of building models to learn different appearance and interior layout alternatives for a comparison of the impact on the real environment, to inform design decision-makings. The function of usable space calculation
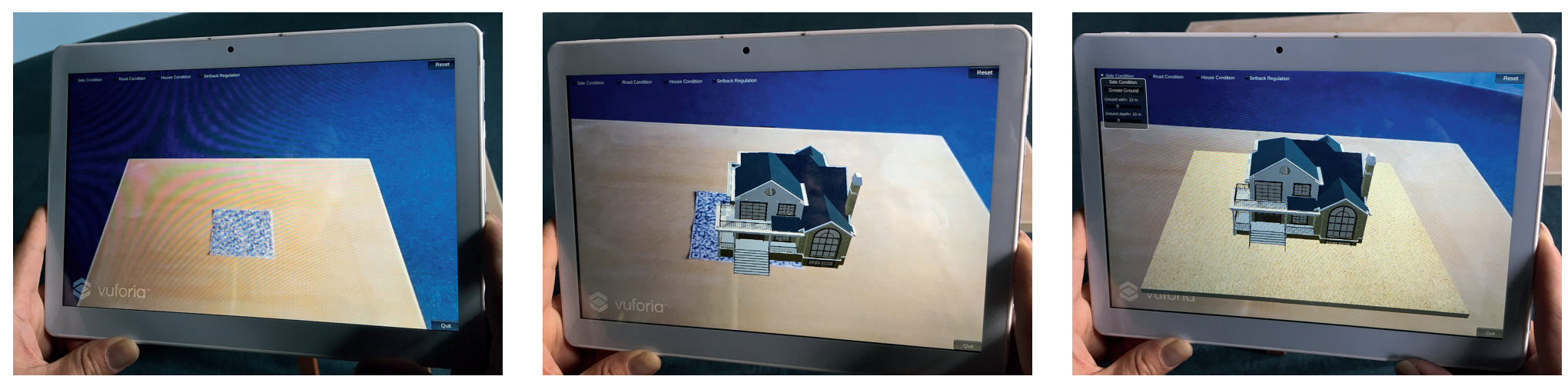

8. 用于检测建筑是否违 反建筑后退红线的ARPST, 用户可通过平板 电脑访问该工具的初始 页面。

8. The AR-PST for violation detection of building setback line. Users can use tablets to access the initial page of AR-PST.
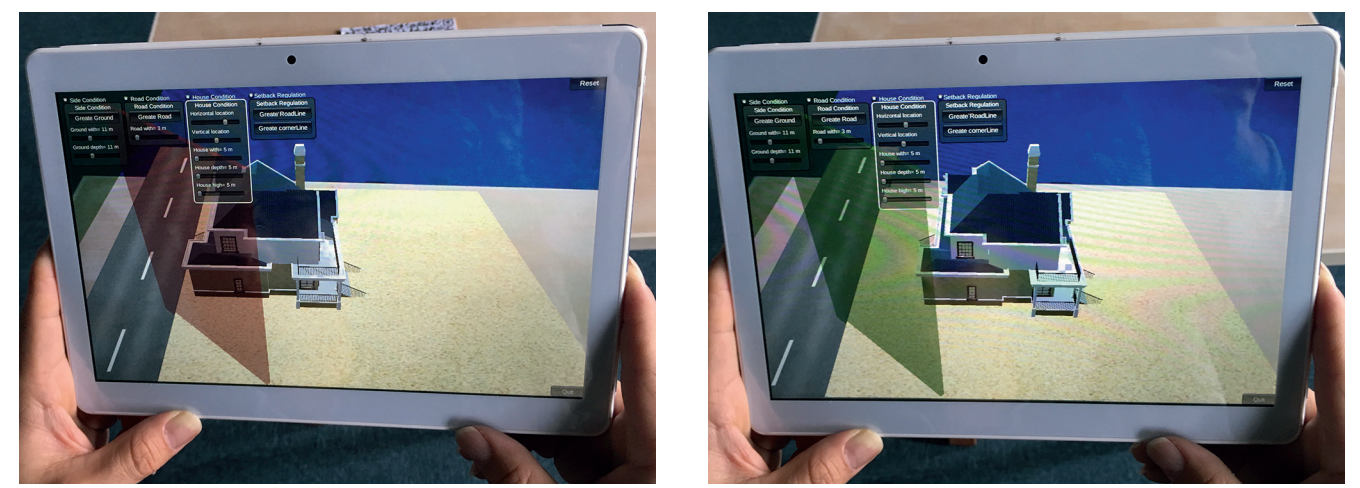
is developed to indicate the FAR and BCR of different design proposals. For the building regulation verification function, users need to determine the land use zone of the site and then set the building form parameters, such as height limit, road slantplane restriction, north slant-plane restriction, and neighboring slant-plane restriction. All these done, the tool can tell whether the building model meets the building regulations of Japan by the collision detection technique of Unity 3D.

There are three layers in data processing module: the imaging layer, unity layer, and rendering and displaying layer. The imaging layer consists of various components that deal with imaging and marker ${ }^{2}$ acquisition and tracking. The unity layer consists of C\# scripts repository and the core Unity physics and graphics engine. It acts as an intermediary between the imaging layer and rendering and displaying layer, conveying the drawing calls to the Graphics Processing Unit (GPU) to create virtual building models and positioning them in a virtual $3 \mathrm{D}$ environment. The rendering and displaying layer processes information from the unity layer and outputs the data (real site image, feature points of AR marker, virtual building models, etc.) to mobile device terminals by the virtual model rendering technique.

\subsection{D Modeling and Camera Setting}

The next step after developing the AR-PST was 3D modeling. The research utilized 3D Studio Max to create building models

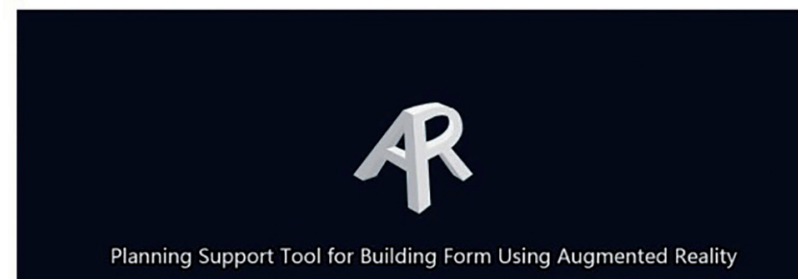

Planning Support Tool for Building Form Using Augmented Reality

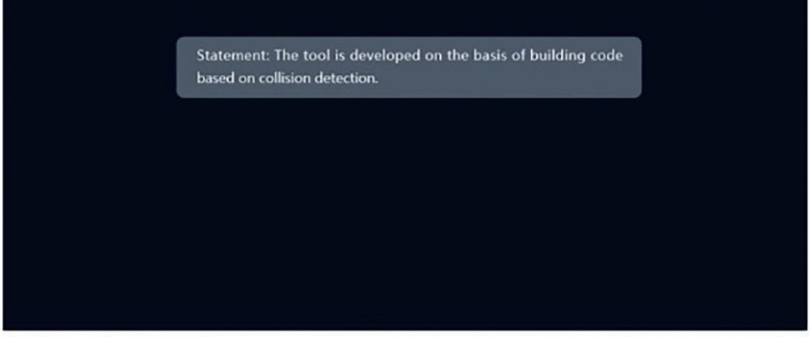

(a) 初始化页面 Initialization

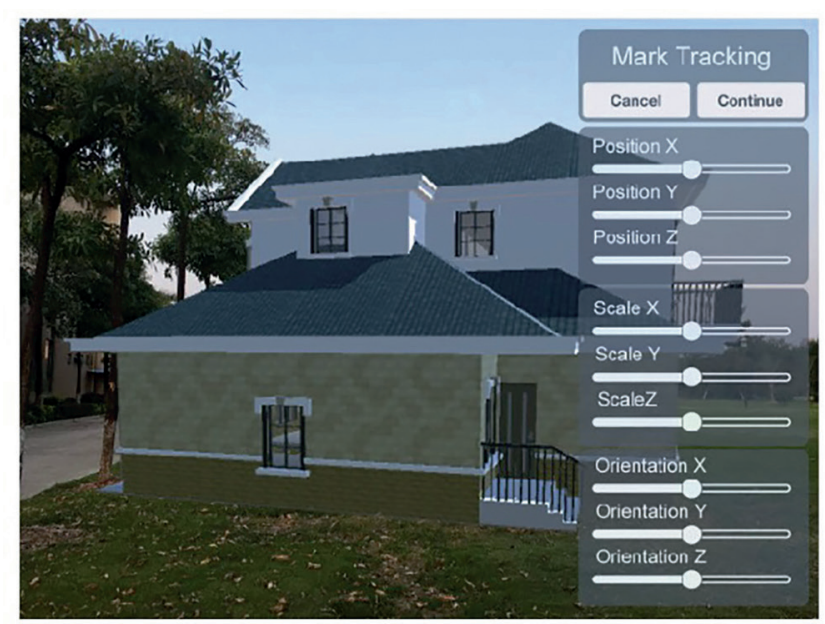

(c) 实时编辑界面

Real-time editing

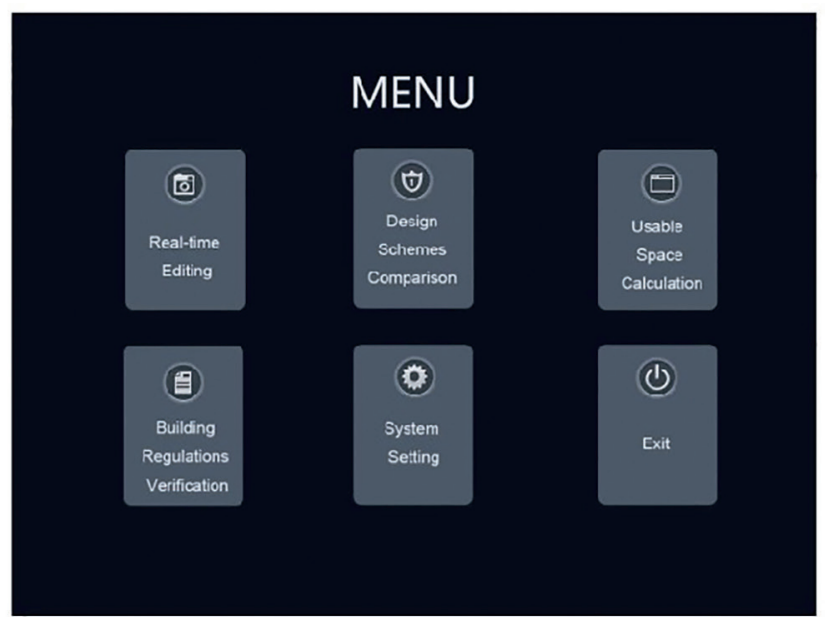

(b) 主菜单界面 Main menu

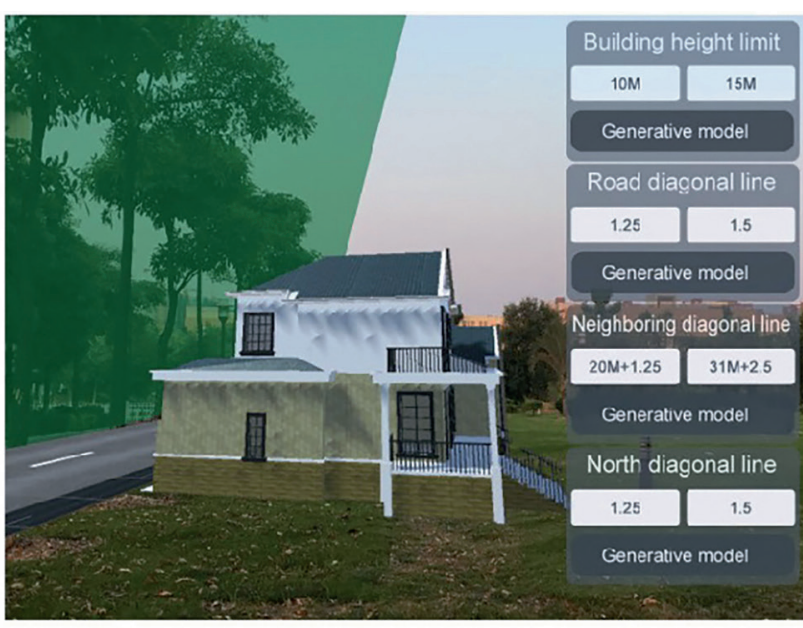

(d) 建筑规范检验界面

Building regulation verification
用于用户体验测试的数据

. The data used for user experience testing 
with various forms and registered a 3D object in ImageTarget hierarchy using Unity Package as the matching coordinates (Fig. 5).

The second step is to set AR Camera. It is used to capture images of objects in the real site to form a rendering background for the virtual building models, so that the user can view the design proposal with a reality-based environment. Through system setting of AR-PST, the camera FRUSTUM's projection type can be defined, as well as the plane and viewport rectangle; the direction, device mode, mirror video background, and world center mode of the AR camera can also be set. The target objects are set by script codes. Through the camera's detection they will be imported into the AR-PST system, and the information of their images will be saved in an XML formant for the system's call.

\subsection{Collision Detection in Checking of Building Setback Line Control}

The violation detection against the building form regulations is realized primarily through collision detection, illustrated with an example of corner cutting detection in Figure 6 and 7. The collision detection of AR-PST is realized with a trigger (based on control regulations) and a collider (the virtual building model): if there is a confliction (a violation against the regulations), the trigger will send a trigger message as an alert. According to the expected value in the trigger message, the user can verify whether the building model meets the corner cutting regulations.

\section{User Experience Investigation}

\subsection{Methods for Investigation}

The user experience investigation can objectively reflect whether the AR-PST is user-friendly or not. It mainly contains users' experience of functionality, interactivity, and fluency of the AR-PST. The results can be obtained by participant cognition, operation experience, and communication with the participants respectively ${ }^{[31]}$. In February, 2017, the joint Spatial Planning and Sustainable Development (SPSD) Lab by Fuzhou University and Kanazawa University invited 20 students from Fuzhou University, who do not major in urban planning and design, to participate in the investigation.

Firstly, participants used tablets to enter the initialization page of AR-PST (Fig. 8). The initialization page displayed the tool's name and statement so that participants can quickly understand that the tool is developed on the basis of building form control regulations and collision detection. Secondly, participants went to the main menu interface and tested the

\begin{tabular}{c|c|c}
\multicolumn{3}{c}{$\begin{array}{c}\text { 表1: 用户体验量表调查的Cronbach } \alpha \text { 信度检验结果 } \\
\text { Table 1: Cronbach's } \alpha \text { values for all scales }\end{array}$} \\
\hline $\begin{array}{c}\text { 调查量表 } \\
\text { Scales }\end{array}$ & $\begin{array}{c}\text { 每个量表的项目数 } \\
\text { Number of items in each scale }\end{array}$ & Cronbach $\alpha$ \\
\hline $\begin{array}{c}\text { 操作评价 } \\
\text { Operation evaluation }\end{array}$ & 5 & 0.703 \\
\hline $\begin{array}{c}\text { 用户反馈调查 } \\
\text { Feedback investigation }\end{array}$ & 4 & 0.716 \\
\hline
\end{tabular}

\begin{tabular}{c|l|c}
\multicolumn{3}{c}{$\begin{array}{c}\text { 表2: 参与者对基于增强现实的规划支持工具的兴趣调查 } \\
\text { Table 2: Participants' interest in the AR-PST }\end{array}$} \\
\hline \begin{tabular}{c}
\multicolumn{1}{c}{ 序号 } \\
No.
\end{tabular} & \multicolumn{1}{|c}{\begin{tabular}{c}
\multicolumn{1}{c}{ 调查项目 } \\
Test items
\end{tabular}} & $\begin{array}{c}\text { 符合描述者占比 } \\
\text { Proportions }\end{array}$ \\
\hline $\mathbf{1}$ & $\begin{array}{l}\text { 对城市规划设计有基本了解。 } \\
\text { Having a general familiarity with urban planning and design. }\end{array}$ & $85 \%$ \\
\hline $\mathbf{2}$ & $\begin{array}{l}\text { 对建筑规范有基本了解。 } \\
\text { Having a general familiarity with urban building regulations. }\end{array}$ & $45 \%$ \\
\hline $\mathbf{3}$ & $\begin{array}{l}\text { 支持增强现实技术在城市规划设计中的应用。 } \\
\text { Believing AR technology be applied in urban planning and design. }\end{array}$ & $75 \%$ \\
\hline $\mathbf{4}$ & $\begin{array}{l}\text { AR-PST很有趣且有意义。 } \\
\text { Believing the AR-PST very interesting and promising. }\end{array}$ \\
\hline
\end{tabular}

performance of each function and the sensitivity of the humancomputer interaction by screen touch. The whole investigation was conducted in the campus of Fuzhou University with three design cases (Fig. 9). Thirdly, the participants were required to fill out a questionnaire, reporting their basic information, operation evaluation, and feedback investigation (the latter two parts were in form of the modified Liker Scale) about the tool.

\subsection{Investigation Result Analyses}

Internal consistency reliability is used to indicate the consistency degree of the questionnaire investigation results, and the result reliability of scale and questionnaire investigations. It is usually measured by Cronbach's $\alpha$, a statistical value calculated from the interdependency among the investigated items ranging between 0 and $1-$ the more it approaches 1 , the higher reliability the investigation has. Table 1 illustrates the Cronbach's alpha values for all scales in this investigation. The results indicated that the Cronbach's $\alpha$ values are above 0.70, showing a good reliability.

Participants' tendentiousness of AR-PST was clearly indicated by the questionnaire results. Table 2 shows that most of the participants $(85 \%)$ have a general familiarity with urban 
表3：软件操作评价与用户反馈调查的结果

Table 3: The results of operation evaluation and feedback investigation

\begin{tabular}{|c|c|c|c|}
\hline $\begin{array}{l}\text { 序号 } \\
\text { No. }\end{array}$ & $\begin{array}{l}\text { 调查项目 } \\
\text { Test items }\end{array}$ & $\begin{array}{l}\text { 选项 } \\
\text { Options }\end{array}$ & $\begin{array}{l}\text { 选择此项的人数占比 } \\
\text { Proportions }\end{array}$ \\
\hline \multirow{4}{*}{1} & \multirow{4}{*}{$\begin{array}{l}\text { 此工具中用户最感兴趣的一个功能模块 } \\
\text { Which functional module of the PST interested the } \\
\text { user the most? }\end{array}$} & A. 建筑模型实时编辑 Real-time editing & $10 \%$ \\
\hline & & B. 设计方案对比 Design scheme comparison & $45 \%$ \\
\hline & & C. 可用空间计算 Usable space calculation & $15 \%$ \\
\hline & & D. 建筑合规性检验 Building regulation verification & $30 \%$ \\
\hline \multirow{5}{*}{2} & \multirow{5}{*}{$\begin{array}{l}\text { 用户对此工具中最感兴趣功能模块的满意度 } \\
\text { User's evaluation of the functional module that } \\
\text { interests participants the most. }\end{array}$} & A. 非常满意 Strongly satisfactory & $40 \%$ \\
\hline & & B. 满意 Satisfactory & $50 \%$ \\
\hline & & C. 无倾向 Neither satisfactory nor unsatisfactory & $10 \%$ \\
\hline & & D. 不满意 Unsatisfactory & l \\
\hline & & E. 非常不满意 Strongly unsatisfactory & I \\
\hline \multirow{3}{*}{3} & \multirow{3}{*}{$\begin{array}{l}\text { 此工具有助于提高设计师与客户之间的沟通效率。 } \\
\text { The tool helps improve the communication } \\
\text { efficiency between designers and users. }\end{array}$} & A. 是的, 有帮助 Yes & $90 \%$ \\
\hline & & B. 不确定 Uncertain & $10 \%$ \\
\hline & & C. 无帮助 No & 1 \\
\hline \multirow{3}{*}{4} & \multirow{3}{*}{$\begin{array}{l}\text { 用户能顺利找到各功能模块。 } \\
\text { The user can identify the function modules } \\
\text { successfully. }\end{array}$} & A. 是的, 可以 Yes & $85 \%$ \\
\hline & & B. 一般 Tolerable & $15 \%$ \\
\hline & & C. 较困难 No & l \\
\hline \multirow{3}{*}{5} & \multirow{3}{*}{$\begin{array}{l}\text { 此工具对城市规划设计工作有帮助。 } \\
\text { The tool can assist urban planning and design. }\end{array}$} & A. 是的, 有帮助 Yes & $75 \%$ \\
\hline & & B. 无帮助 No & 1 \\
\hline & & C. 不确定 Uncertain & $25 \%$ \\
\hline \multirow{3}{*}{6} & \multirow{3}{*}{$\begin{array}{l}\text { 各功能模块之间衔接流畅 } \\
\text { The cohesion between the functional modules is } \\
\text { smooth. }\end{array}$} & A. 是的, 很流畅 Yes & $90 \%$ \\
\hline & & B. 不够流畅 No & I \\
\hline & & C. 流畅程度一般 Tolerable & $10 \%$ \\
\hline \multirow{4}{*}{7} & \multirow{4}{*}{$\begin{array}{l}\text { 人机交互界面 ( 如手动触摸区域 ) 的灵敏度较高 } \\
\text { The sensitity of human-computer interaction (le.g.. } \\
\text { manual touch) is satisfactory. }\end{array}$} & A. 是的, 很灵敏 Yes & $80 \%$ \\
\hline & & B. 比较灵敏 Well enough & $20 \%$ \\
\hline & & C. 灵敏度一般 Tolerable & 1 \\
\hline & & D. 灵敏度较差 No & 1 \\
\hline \multirow{6}{*}{8} & \multirow{6}{*}{$\begin{array}{l}\text { 与仅能在全虚拟环境下汶览的传统规划支持系统相 } \\
\text { 比, 此工具最大的特色是哪一项? (对右侧 } \text { 个选 } \\
\text { 项进行排予; 本表统计结果为各选项出现在首位的 } \\
\text { 次数占比) } \\
\text { The characteristics of the tool, compared to } \\
\text { conventional planning support systems that only } \\
\text { work in virtual reality. (Users were asked to rank the } \\
\text { six options; the proportions listed the rankings) }\end{array}$} & A. 智能性 Intelligence & l \\
\hline & & B. 趣味性 Interesting & $45 \%$ \\
\hline & & C. 灵活性 Flexibility & $20 \%$ \\
\hline & & D. 互动性 Interactivity & $35 \%$ \\
\hline & & E. 吸引力 Fascinating & I \\
\hline & & F. 教育性 Educational & I \\
\hline \multirow{4}{*}{9} & \multirow{4}{*}{$\begin{array}{l}\text { 调研参与者是否喜欢此工具 } \\
\text { Whether participants like this tool. }\end{array}$} & A. 是的, 很喜欢 Yes & $65 \%$ \\
\hline & & B. 比较喜欢 Well enough & $25 \%$ \\
\hline & & C. 无明显倾向 No preference & $10 \%$ \\
\hline & & D. 不喜欢 No & I \\
\hline
\end{tabular}

planning and design; in contrast, their understanding level of building regulations is far lower, which may be enhanced by the AR-PST. 75\% of the participants regarded AR-PST as interesting and meaningful, and those supporting to apply AR technology in urban planning and design also account for $75 \%$. Some of the objectors thought that the overlapping performance of virtual building models and actual project plots is barely satisfactory, so the AR technology is still underdeveloped.

The results of the operation evaluation and feedback investigation of AR-PST are shown in Table 3. Among all the participants, $90 \%$ believed that AR-PST can help improve the communication efficiency between designers and users; $90 \%$ appreciated the cohesion between each functional module; $85 \%$ of them can identify all the function modules successfully; $80 \%$ participants were strongly satisfied with the sensitivitiy of humancomputer interaction. Moreover, $75 \%$ of the participants held that AR-PST can assist urban planning and design; $65 \%$ of them liked AR-PST. Interestingness, interactivity, and flexibility are three main advantages of AR-PST in comparison to conventional PSSs that only work in VR. Specifically, interestingness means that AR-PST can present the textual building regulations in form of 3D models, which are easier to understand; interactivity indicates the excellent experience of screen touch and human-computer interaction, and the dynamic presentation of design proposals; and flexibility reflects that AR-PST can easily realize switches of visual angle and the real-time editing of building models.

\section{Conclusions}

The AR-PST developed in this research allows users to better understand and evaluate building design proposals under building control regulations in real construction sites, so as to help improve the communication efficiency between designers and users. The results of user experience testing indicate that the AR-PST has shown creative functional design and excellent interactivity in the process of violation detection against building form control. In the future, AR-PST is expected to be applied into more practical cases, for a more reasonable analysis of the usable space of buildings considering all planning regulations and the enhancement of its better application in urban planning management. LAF

\section{PROJECT INFORMATION}

Technological Director: Shen Zhenjiang

Development Team (key members): Cheng Jiaohua, Zhang Yuanyi, Kawakami Mitsuhiko Development Period: 2016

User Experience Investigation Team: Students of FZUKU-LAB SPSD 
[1] Niu, X. Y. (2006). Planning support system: A new approach for computer-aided planning. Urban Planning Forum, (2), 96-101.

2] Shen, Z J. (2012) Geospatial Techniques in Urban Planning. Berlin: Springer.

[3] Willuweit, L, \& O'Sullivan J. J. (2013). A decision support tool for sustainable planning of urban water systems: Presenting the dynamic urban water simulation model. Water Research, 47(20), 7206-7220.

[4] Yeo, I. Yoon, S., \& Yee, J. (2013). Development of an urban energy demand forecasting system to support environmentally friendly urban planning. Applied Energy, 110(5), 304-317.

[5] Blečić, L, Cecchini, A. Falk, M. Marras, S, Pyles, D. R., Spano, D., \& Trunfi, G.A. (2014). Urban metabolism and climate change A pla. A. (2014). Ur ban metabolismand Journal of Applied Earth Observation and Geoinformation, (26), 447-457. https://doi.org/10.1016/j.jag.2013.08.006

[6] Long, Y., Shen, Z. J., \& Mao, Q. Z. (2011). An urban containment planning support system for Beijing. Computers Environment and Urban Systems, 35(4), 297-307.

[7] Kim, Y. M., Bang, J., \& Kim, H. S. (2012). A planning support system as a tool for sustainable urban planning. In M. Schrenk, V. V. Popovich, P. Zeile, \& P. Elisei (Eds.), Proceeding REAL CORP 2012 Tagungsband (pp. 1111-1119). Schwechat, REAL CORP 2012 Tagungsb

[8] Coutinho-Rodrigues, J., Simão, A. \& Antunes, C. H. (2011). A GIS-based multicriteria spatial decision support system for planning urban infrastructures. Decision Support Systems, 51(3), 720-726. https://doi.org/10.1016/j.dss.2011.02.010

[9] Inada, Y., Izumi, S., Koga, M., \& Matsubara, S. (2014). Development of planning support system for welfare urban design - Optimal route finding for wheelchair users. Procedia Environmental Sciences, (22), 61-69. https://doi.org/10.1016/ Environmental Scien

[10] Fukahori, K., \& Kubota, Y. (2010). Consistency Evaluation of Landscape Design by Decision Support System. ComputerAided Civil and Infrastructure Engineering, 15(5), 342-354.

[11] Santosa, H., Ikaruga, S., \& Kobayashi, T. (2016). 3D Interactive Simulation System (3DISS) Using Multimedia Application Authoring Platform for Landscape Planning Support System. Procedia - Social and Behavioral Sciences, (227) 247-254. https://doi.org/10.1016/j.sbspro.2016.06.068

[12] Liarokapis, F. \& Anderson, E. F. (2010). Using augmented reality as a medium to assist teaching in higher relity as a medich In Proceeding European Association for Computer Graphics (Eurographics 2010), Education Program (pp. 9-16). Norrköping, Sweden: Eurographics Association.

[13] Raajana, N. R., Suganya, S., Hemanand, R., Janani, S., Nandini. N. S. S., \& Ramanan, S. V. (2012). Augmented Reality for 3D Construction. Procedia Engineering, (38), 66-72.

[14] Caudell, T. P. \& Mizell, D. W. (1992). Augmented reality: An application of heads-up display technology to manua manufacturing processes. In Proceedings of the Twenty-Fith manulacturing processes. In Proceedings of the Twenty-Fifth 669). New York: IEEE.

[15] Pelargos, P., Nagasawa, D. T., Lagman, C., Tenn, S., Demos, J. V., Lee, S. J. ... Yang, I. (2017). Utilizing virtual and augmented reality for educational and clinical enhancements in neurosurgery. Journal of Clinical Neuroscience, 35(36), 1-4.

[16] Wang, R., Geng, Z., Zhang, Z. X., Pei, R. J., \& Meng, X. B. (2017). Autostereoscopic augmented re Autostereoscopic augmented reality visualization for depth

[17] Akcayır. M. \& Akcayır, G. [2017). Advantages and challenges associated with augmented reality for education: A systematic review of the literature. Educational Research Review, 20(20) $1-11$

[18] Alhumaidan, H., Lo, K. P. Y., \& Selby, A. (2017). Co-designing with children a collaborative augmented reality book based on a primary school textbook. International Journal of ChildComputer Interaction, (15), 24-36.

[19] Tsai, C. H., \& Huang, J. Y. (2018). Augmented reality display based on user behavior. Computer Standards \& Interfaces, (55), 171-181

[20] Chi, H. L., Kang, S. C., \& Wang, X. Y. (2013). Research trend and opportunities of augmented reality applications in architecture, engineering, and construction. Automation in Construction, (33), 116-122.

[21] The App Solutions. (2015). Benefits of using augmented reality for business. Retrieved from https://theappsolutions.com/ blog/development/ar-benefits-for-business/
[22] Dieck, M. C. T., \& Jung, T. H. (2017). Value of augmented reality at cultural heritage sites: A stakeholder approach. Journal of Destination Marketing \& Management, 6(2), 110117.

[23] Han, J., Park, K., Ban, K., \& Kim, E. (2013). Cultural heritage sites visualization system based on outdoor augmented reality. AASRI Procedia, (4), 64-71.

[24] Rashid, Z., Melià-Seguí, J., Pous, R., \& Peig, E. (2017). Using augmented reality and internet of things to improve accessibility of people with motor disabilities in the context of smart cities. Future Generation Computer Systems, (76), 248261.

[25] Blümel, E. (2013). Global challenges and innovative technologies geared toward new markets: Prospects for virtual and augmented reality. Procedia Computer Science, (25), 4-13.

26] Zhang, Y. Y., Shen, Z. J. \& Liu, S. H. (2018). Virtual Reality with the Integrated Automatic Presentation Scrip for Improving Concepts Understanding of Urban Design - A Case Study in Tatsumi Region of Tokyo Bay Zone, Japan. Multimedia Tools and Applications. https://doi.org/10.1007/s11042-018-6588-y

[27] Cirulis, A., \& Brigmanis, K. B. (2013). 3D outdoor augmented reality for architecture and urban planning. Procedia Computer Science, (25), 71-79.

[28] Ministry of Land, Infrastructure, Transport and Tourism Japan. (2003). Introduction of Urban Land Use Planning System in Japan. Retrieved from http://www.mlit.go.jp/ common/001050453.pdf

[29] Sapry, A. D. (2017). Factors hindering the implementation of augmented reality (AR) in Malaysian construction. Retrieved from Faculty of Civil Engineering and Earth Resources, University Malaysia Pahang website: http://umpir.ump.edu my/id/eprint/21124/

[30] Kim, D., \& Hwang, D. (2012). Non-Marker based Mobile Augmented Reality and its Applications using Object Recognition. Journal of Universal Computer Science, 18(20) 2832-2850

[31] Hassenzahl, M., \& Tractinsky, N. (2006). User Experience - A Research Agenda. Behavior \& Information Technology, 25(2), 91-97. 